\title{
Practical Abilities Improved by CDIO Teaching Mode Taking the Course of Integrated English as an Example
}

\author{
Xiao Wenwen ${ }^{1} \&$ Gu Yunfei ${ }^{1}$ \\ ${ }^{1}$ School of Foreign Languages, Leshan Normal University, Leshan, China \\ Correspondence: Xiao Wenwen, School of Foreign Languages, Leshan Normal University, Leshan, China. Tel.: \\ 86-183-8334-0090. E-mail: 949864462@qq.com
}

Received: July 31, 2018 Accepted: September 10, 2018 Online Published: September 21, 2018

doi: 10.5539/elt.v11n10p109 URL: http://doi.org/10.5539/elt.v11n10p109

\begin{abstract}
The CDIO teaching mode is one kind of the engineering education concept, and now it is gradually adopted in English language teaching. Integrated English is one of the basic courses for English major students, and adopting the CDIO teaching mode in this course can improve different abilities of English major students, such as the professional knowledge of English, ability to find and solve the problems, self-learning ability, related employment ability, critical thinking ability, teamwork spirit and innovation ability.
\end{abstract}

Keywords: CDIO teaching mode, practical abilities, integrated English

\section{Introduction}

Now some teachers are trying to adopt the CDIO teaching mode and making a reform of language teaching. At the very beginning, CDIO was adopted in engineering education. The adopting of CDIO teaching mode in English teaching can make the students improve their English application ability on one hand, and improve their other abilities on the other, such as the teamwork spirit, critical thinking ability and so on.

\section{Research Background}

In China, nowadays there are a lot of undergraduates choosing the English major, but it is a trend that the English majors cannot get a good job after their graduation, for there are too many graduates of English major or the employers cannot find the qualified graduates. The graduates of English major are required to have professional knowledge in English as well as work competence. Therefore, the requirements for the courses teaching of English major are getting higher and higher.

There are many courses for English major, and Integrated English is one of the compulsory courses for the freshmen and sophomores. In this course, the teacher is required to cultivate the comprehensive ability of students: listening, speaking, reading, writing and translating. In Leshan Normal University, this course is set for the first two years of English major, lasting for four semesters with six periods each week. This course is of great significance to make the solid foundation. Theoretically speaking, Integrated English is the most suitable course to cultivate the practicable abilities of the students of English major (Tang, 2009). For the Integrated English teachers, it is really hard to arrange six periods within one week, adopting different teaching methods.

Normally, the Integrated English classes mainly focus on the pronunciation, words and phrases, sentences and content of the texts in each unit. These factors are essential to the English language learning. Nowadays, most teachers can combine the traditional teaching methods with the modern and advanced ones. For example, the lecture-style teaching method, demonstration method, grammar-translation method, inquiry teaching method, task-based approach, discussion approach and so on. The combination of these methods can make the students not only learn the basic knowledge of the English language but also improve their abilities of thinking and teamwork. However, the present society has higher demands on the students' abilities after their graduation. Therefore, it is necessary for the Integrated English teachers to adopt different teaching modes to improve the students' abilities.

\section{Theoretical Basis}

CDIO teaching mode is a kind of engineering education concept initiated by Massachusetts Institute of Technology, KTH Royal Institute of Technology and two other institutes, which refers 


\section{Conceive-Design-Implement-Operate (abbreviated as CDIO).}

This teaching mode takes the production of one product as the carrier: from the conception, research and development, operation, abandonment and recycling of the product, guide the students to learn actively, practically to grasp the organic connection among professional knowledge, and cultivate their abilities, such as scientific and technical knowledge, life-long learning ability, communication ability, teamwork spirit as well as the ability to construct the product, process and system under the environment of society and enterprise ( $\mathrm{Gu}, \mathrm{Lu}$, $\&$ Shen, 2008).

At the very beginning, only the engineering courses adopt the CDIO teaching mode, and now the language teaching adopts this mode in more and more courses. The foreign languages teaching should include the following two skills at least: linguistic skills and professional skills, and the interdisciplinarity of the CDIO teaching mode can realize the breakthrough of the foreign language teaching reform (Zhu, 2010).

\section{Practical Abilities Improved by CDIO Teaching Mode}

For the course of Integrated English, now the teachers are asked not only to teach the basic abilities of English: listening, speaking, reading, writing and translating, but improve other abilities related to the students' future work, study and life. For the CDIO teaching mode, when one project is carried out, the main work of the teacher is to create the resources and environment of learning, in order to make the students enjoy more opportunities to use the learnt knowledge in different situations (Yao, 2007). In this part, the author will take the textbook of Integrated English 3 adopted by Leshan Normal University (with Yang Limin as the editor-in-chief) as an example to show how the CDIO teaching mode improves different abilities of English major students.

\subsection{Professional Knowledge of English}

The professional knowledge is the basic requirement for Integrated English as a basic course for English major. The traditional teaching methods can definitely meet this demand, so does the CDIO teaching mode. For the CDIO teaching mode, the professional knowledge of English should be found out by the students themselves through different projects under the guidance of the teacher. For the author, when she carries out the CDIO teaching mode, the students are required to finish the curricular and extra-curricular projects for each unit within certain period.

Different from the traditional teaching methods, the CDIO teaching mode requires the students to complete the projects by themselves under the teacher's guidance. Therefore, in order to complete each project, the students have to understand the meaning of the text and grasp the basic knowledge in the text, and this part is mainly carried out by themselves.

For each unit, the students should grasp the basic knowledge of the unit within in curricular project, firstly by themselves. If there are some problems in understanding the text, they should try to solve these problems through discussion with other group members. At last, if there are still some problems unsolved, the teacher will give them certain clues to solve these problems.

Besides, it's also necessary to make an evaluation system to evaluate whether the students have really grasped the professional knowledge of English in each unit. For example, the author carries out one quiz for every two units, to check the understanding of the students. Meanwhile, the final presentation of the curricular and extracurricular projects is also a method to show whether they have grasped the important point in the text.

\subsection{Ability to Find and Solve the Problems}

For the CDIO teaching mode, the teacher just guide the whole plan of each project, and it's the students' task to find out the detailed problems in each project and try to find out how to solve these problems.

For most projects in this course, the students can be trained to improve their ability to find and solve the problems. For example, in Unit 2 How Reading Changed My Life, the students are required to present their book promotion each group. In order to present the book promotion at last, they must learn what a book promotion is, how to arrange it, what kinds of problems will be met with, and what they can do to solve these problems. Under the guidance of the teacher, the students can find and solve these detailed problems by themselves. Through the practice of different projects, the students can try to find and solve the problems in their life, and future work.

\subsection{Self-Learning Ability}

Different from the traditional teaching methods, the CDIO teaching mode asks the students to learn some related knowledge by themselves. 
As mentioned in the section of profession knowledge of English, the students should learn the texts by themselves at first, so this process can improve the students' self-learning ability. Beside, in order to complete each extracurricular project, the students should learn different aspects related to the project by themselves.

For example, the extracurricular project for Unit 4 Text A Diogenes and Alexander is to make Moments for the celebrities mentioned in this text, such as Diogenes, Alexander, Aristotle, Plato, and so on. If these celebrities in the ancient time also had Wechat, how would their Moments look like? In order to finish this project, first the students should learn the text by themselves, and then get more information on each person after class to make this person more vivid. Besides, the students also need to learn how to make "Moments". Only after they learn these skills by themselves, can they complete the project well. All these improve their self-learning ability.

\subsection{Related Employment Ability}

Now the English major students are always faced with great employment pressure after their graduation. Through different projects, the students can improve their abilities related to their future work, for example, the teaching ability, translating ability, foreign trade ability and so on. All the projects can prepare the students well for their future employment.

For the first unit in this textbook, Your College Years, the author arranges a project: Simulation Job Fair. In this project, some of the students are appointed as the "employers" while others "employees". This employment covers different areas related to English, such as the English teachers, translators, interpreters, foreign trade personnel and so on. In order to complete this project, all "employers" and "employees" must learn the basic knowledge on the requirements of each occupation. For example, to be employed as an English teacher, the "employees" must have the basic teaching skills, accurate pronunciation, fluent expression, beautiful blackboard-writing and so on. After this employment is stimulated in the class, the teacher will give some evaluation on their performance and the students will then discuss on how to get their dream work after graduation.

\subsection{Critical Thinking Ability}

The undergraduates should not just memorize the existing knowledge, and during their study they should also have their own thinking. Besides, the present society also requires the graduates to have the critical thinking ability, which is also beneficial to their future jobs.

For Unit 8 In My Day, this text talks about the relationship between the author and his mother. The ageing problem now is very popular and great in China, so the author arranges two students to arrange the discussion among all the students. The questions for their discussion are as follows: 1. Do you think it a good idea to send one's ageing parents to a nursing home? Give your reasons. 2. How do you think about the DINK (Double Income No Kids) family? For these questions, there are no standard answers, and everyone can share his or her opinion.

\subsection{Teamwork Spirit}

The course of Integrated English takes six periods each week, and under the CDIO teaching mode, the teacher can design different kinds of projects for the students to carry out, such as the project for each group and the project for the whole class. These projects can improve the participants' teamwork spirit.

Most of the projects for Integrated English 3 are designed as group projects, and each group member should play a certain role in each project. Besides, the teacher arranges a project for the whole class in Unit 6 How do We Deal with the Drug Problem. After learning this unit, the class will present one debate as a whole. At first, one director will be appointed to arrange every detail from the preparation to the final presentation. Then this director will arrange four debaters for each side, the judges, and other working personnel. After each one gets his or her position, they will cooperate with other students, and at last the final presentation of this debate is the contribution of every one. During this project, the students can learn how to work in a large team, which is also beneficial to their future work.

\subsection{Innovation Ability}

The present education also pays more attention to students' innovation ability. The students should have the innovation ability as well as the professional knowledge. The author still focuses on creating the students' innovation ability.

At first, their innovation ability can be improved the performance. For Unit 3 A Dill Pickle, the author asks her students to show their performance after adaption, which is based on the original text. For Unit 8 In My Day, the students are required to make a completely new story, while each story should focus on the topic of this unit: 
family. In order to present their final performance, the students should make some innovations.

Then for Unit 5 Silent Spring, whose topic is environmental protection, the students are asked to present their innovation ability to draw a poster, write a short play, or make some handicrafts. Some groups draw some posters, and they have their own designs and ideas, while most groups choose to make handicrafts about environmental protection, such as the pen container made of the wasted ice cream sticks, the cat's house made of the wasted box, the wedding dress made of the wasted bed net and other clothes. All these show their innovation ability.

Different projects can be carried out by the students under the guidance of the teacher to cultivate the professional practical abilities of the students of the English major. As mentioned above, it can improve the students' professional knowledge of English, ability to find and solve the problems, self-learning ability, related employment ability, critical thinking ability, teamwork spirit and innovation ability. As a new kind of teaching mode, CDIO teaching in English encourages us to get continuous improvement and perfection at the same time of adding the fresh blood into the traditional English teaching (Yang, 2011).

\section{Conclusion}

Through the teaching practice, it can be proved that the CDIO teaching mode can be adopted in the teaching of the Integrated English, and this teaching mode can also improve the students' abilities. However, the CDIO teaching mode also has higher requirements for the teachers. Teaching benefits teachers as well as students. The CDIO teaching mode is a better way to improve the students as well as the teachers. In the future, this teaching mode can also be adopted in different subjects teaching and more research can be carried out.

\section{Acknowledgements}

This research is financed by the following program: Education and Teaching Reform Research Program, Leshan Normal University. Program No.: JG2015-YB10.

\section{References}

Gu, P. H., Lu, X. H., \& Shen, M. F. (2008). CDIO Syllabus and Standards. Shantou: Shantou University Press.

Tang, H. J. (2009). On Cultivating Professional Practical Abilities of Undergraduates in the Course of Integrated English. Shandong Foreign Language Teaching Journal, 131(4), 49-53.

Yang, L. M. (2012). Contemporary College English Intensive Reading 3 (2nd ed.). Beijing: Foreign Language Teaching and Research Press.

Yang, Y. (2011). Application of CDIO Teaching Method in Intensive Reading for English Major. Journal of Tianjin Academy of Educational Science, 5, 95-96.

Yao, L. J. (2007). Application of Project Teaching Method in Teaching. Journal of Education Institute of Taiyuan University, 25(2), 80-83.

Zhu, F. (2010). A Study of Project Teaching Approach in China-Also on Applicability of Project Teaching Approach to Foreign Language Teaching in China. Theory and Practice of Education, 30(9), 54-56.

\section{Copyrights}

Copyright for this article is retained by the author(s), with first publication rights granted to the journal.

This is an open-access article distributed under the terms and conditions of the Creative Commons Attribution license (http://creativecommons.org/licenses/by/4.0/). 